
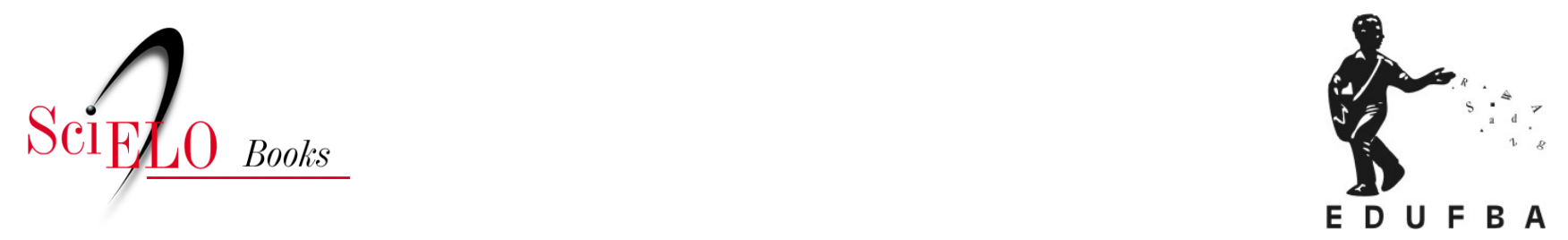

\title{
Parte I - Fundamentos teóricos \\ Realçando o papel da ética e da política na educação científica: algumas considerações teóricas e práticas sobre questões sociocientíficas
}

\author{
Derek Hodson
}

\section{SciELO Books / SciELO Livros / SciELO Libros}

HODSON, D. Realçando o papel da ética e da política na educação científica: algumas considerações teóricas e práticas sobre questões sociocientíficas. In: CONRADO, D.M., and NUNES-NETO, N. Questões sociocientíficas: fundamentos, propostas de ensino e perspectivas para ações sociopolíticas [online]. Salvador: EDUFBA, 2018, pp. 27-57. ISBN 978-85-232-2017-4. https://doi.org/10.7476/9788523220174.0003.

\section{International license.}

Todo o conteúdo deste trabalho, exceto quando houver ressalva, é publicado sob a licença Creative Commons Atribição 4.0. 


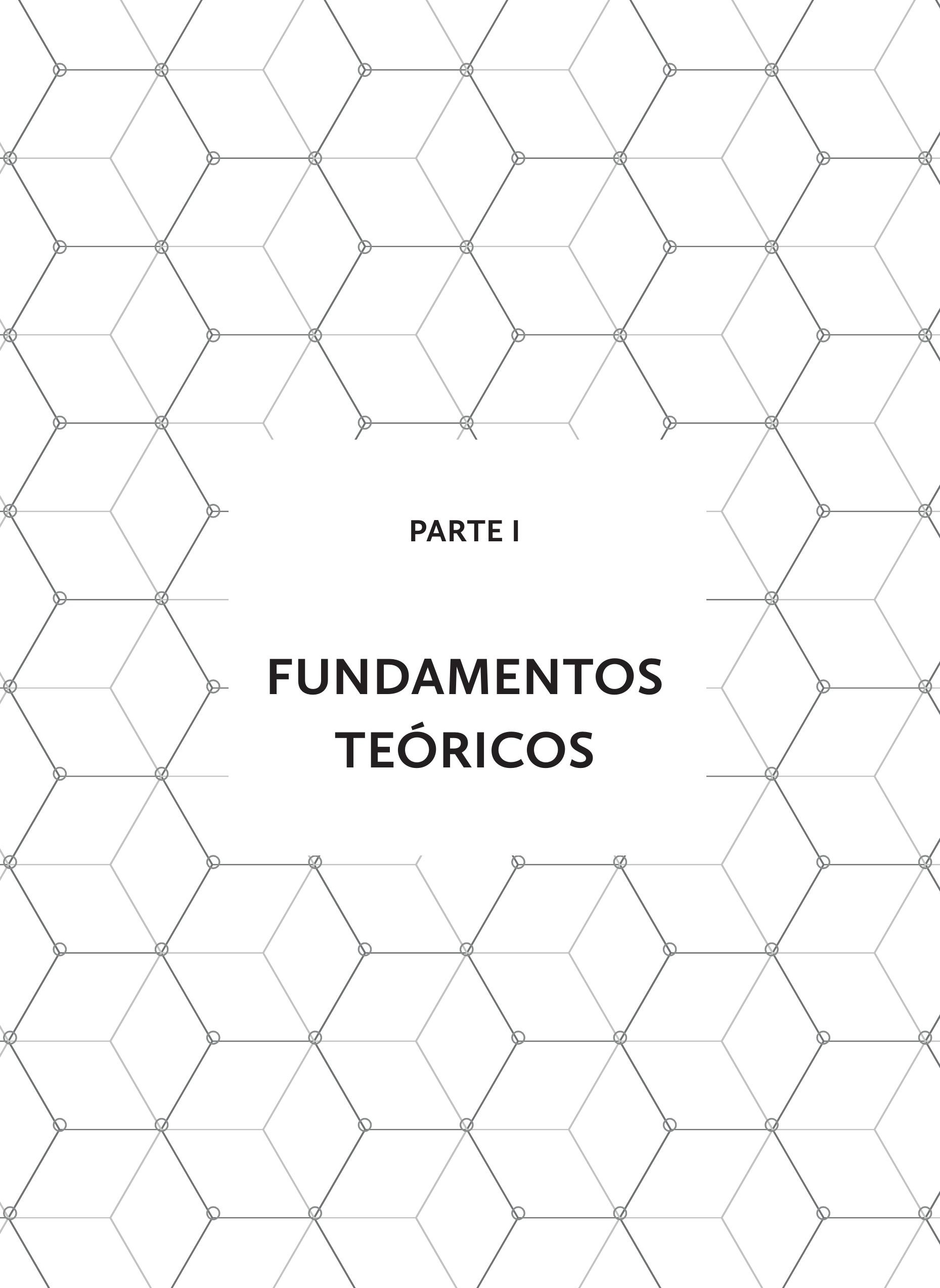




\title{
REALÇANDO O PAPEL DA ÉTICA E DA POLIITICA NA EDUCAÇÃO CIENTÍFICA ALGUMAS CONSIDERAÇÕES TEÓRICAS E PRÁTICAS SOBRE QUESTÕES SOCIOCIENTIIFICAS ${ }^{1}$
}

\author{
Derek Hodson
}

\section{Introdução}

Um argumento convincente para proporcionar aos estudantes oportunidades para enfrentar as Questões Sociocientíficas (QSC), no currículo de ciências e tecnologia, pode ser construído sobre a base de que isto motiva os estudantes, personaliza a aprendizagem, melhora a aprendizagem de conteúdos científicos, contextualiza o entendimento da Natureza da Ciência (NdC) ou Nature of Science (NoS) e envolve os estudantes em situações baseadas em problemas reais, que auxiliam o desenvolvimento de habilidades de pensamento de ordem superior. Alternativamente, pode-se argumentar que não se faz necessária nenhuma outra justificação, além do reconhecimento de que um dos principais objetivos do ensino de ciências é a realização do que Shen (1975) chama de "letramento científico cívico", ou seja, os conhecimentos, habilidades, atitudes e valores para lidar com questões do cotidiano que têm uma dimensão de ciência e/ou tecnologia e, na vida adulta, desempenhar um papel ativo nas tomadas de decisão e na definição de

1 O texto original, em inglês, foi construído a partir de modificações de Hodson (2013). A tradução para o português foi realizada por Nei Nunes-Neto. (N. do O.). 
políticas. Estes argumentos não serão revisados aqui. Em vez disso, a atenção é dirigida para formas nas quais os professores podem construir um currículo coerente e teoricamente justificado, orientado por QSC e planejar uma pedagogia adequada. Primeiro, é necessário selecionar QSC apropriadas. Quais devem ser os critérios de seleção? Deveria ser o interesse do estudante, ou a importância percebida pela sociedade contemporânea, ou a ciência e a tecnologia de ponta, ou a controvérsia viva e pública? Ou deveria ser dada prioridade à disponibilidade imediata de recursos curriculares ou, inversamente, à falta de materiais disponíveis (uma vez que isso exigiria que os estudantes pesquisassem, em busca de mais conhecimento e informação, em si mesmo, um importante objetivo de aprendizagem)? Uma vez que todos estes critérios têm legítimas razões de ser, o ideal pode ser uma combinação equilibrada e consciente de questões significativas, locais, regionais/nacionais e globais, juntamente com uma variedade de QSC escolhidas pelos estudantes de acordo com os seus interesses pessoais.

Parece autoevidente que a maneira mais eficaz de aprender a enfrentar QSC é pelo próprio enfrentamento das QSC, desde que existam níveis adequados de orientação, crítica e apoio de um professor experiente. Especificamente, no contexto de questões pedagógicas e de apoio aos estudantes, o que eu tenho em mente é uma abordagem em três fases, que envolve "modelagem" (o professor demonstra e explica uma abordagem adequada), "prática guiada" (os estudantes executam tarefas específicas com ajuda, crítica e apoio do professor) e "aplicação" (os estudantes realizam a tarefa independentemente do professor). A modelagem do professor (primeira fase) baseia-se na suposição de que a observação e o questionamento de alguém qualificado para enfrentar QSC facilitarão a aprendizagem de estratégias investigativas bem-sucedidas. Na segunda fase (prática guiada), os professores fornecem um programa cuidadosamente sequenciado de investigações durante o qual o papel deles é agir como fonte de aprendizagem, facilitador, consultor e crítico. A suposição é que os estudantes se tornarão mais qualificados para lidar com QSC como uma consequência da prática e da experiência, através do feedback avaliativo fornecido pelo professor e gerado em críticas e discussões intergrupos e, também, através de reflexão intragrupos sobre a atividade, tanto à medida em que ela progride quanto na sua conclusão. Para serem intelectualmente autônomos, no entanto, os estudantes devem, ao final, ser capazes de gerir as situações sem a ajuda do professor e assumir a responsabilidade por planejar, conduzir e relatar suas próprias investigações (a fase de aplicação).

\section{Compreendendo a Ciência}

Para que os estudantes abordem QSC em suas vidas diárias, em qualquer nível além do meramente superficial, eles precisam de, pelo menos, algum conhecimento científico relevante. $\mathrm{O}$ senso comum nos diz que aqueles que conhecem mais sobre a ciência subjacente a uma determinada QSC estarão melhor posicionados para entender os pro- 
blemas, avaliar diferentes posições, chegar às suas próprias conclusões, tomar uma decisão informada sobre onde se encontram em relação à questão e argumentar a favor de seus pontos de vista. Questões cruciais sobre o currículo dizem respeito à profundidade de conhecimento exigida e ao modo pelo qual este deve ser adquirido. Parece quase trivial afirmar que o nível de conhecimento científico necessário é o que é suficiente para capacitar os estudantes a compreender a natureza do problema e que poderia constituir evidência apropriada sobre a qual eles poderiam basear suas tomadas de decisão, e que este nível variará substancialmente de questão para questão. Se o conhecimento científico deve ser adquirido através da instrução prévia ou, alternativamente, à medida em que a necessidade surge, é algo que deve ser decidido caso a caso. Como é frequente o caso na educação, não existe uma resposta universal; diferentes situações exigem diferentes abordagens e diferentes QSC criam necessidades bastante diferentes de conhecimento. Muito depende de se todo o currículo está baseado numa abordagem orientada por QSC ou se as QSC são incluídas como meros ítens acessórios para um currículo, na verdade, orientado por conteúdo, e, ainda, se esse conteúdo particular de ciência será, provavelmente, ensinado e utilizado em outras partes do currículo.

Às vezes, um conhecimento especializado bem além da ciência é necessário. Por exemplo, a fim de abordar a "crise da fossa séptica" em sua escola, os estudantes, no estudo de Pedretti (1997), necessitaram de conhecimento técnico sobre sistemas de fossa séptica, práticas de gestão de resíduos, métodos de filtração, riscos ambientais e regulamentações do governo local. Da mesma forma, aqueles que pretendem avaliar os riscos à saúde, devido às linhas de transmissão de energia elétrica, centrais nucleares ou ao despejo de resíduos tóxicos, necessitarão de um considerável e relevante conhecimento tecnológico. Tentar determinar de forma antecipada exatamente que conhecimento tecnológico será necessário para lidar com uma variedade de QSC é praticamente impossível, especialmente se as questões da atualidade são estudadas apenas por um curto período de tempo. Proporcionar tal conhecimento, à medida em que a necessidade surge, parece a única abordagem prática.

É impossível dotar os estudantes com um conhecimento completo em primeira mão de toda a ciência subjacente a cada QSC relevante. Além disso, dado o ritmo de desenvolvimento científico e tecnológico, é provável que alguma parte do conhecimento científico que os estudantes necessitarão para tomar decisões informadas acerca de uma QSC relevante - que podem encontrar mais tarde na vida - pode, ainda, estar para ser descoberta. No entanto, nós, de fato, sabemos quais são os conhecimentos, as habilidades e as atitudes essenciais para uma apreciação de relatórios científicos e uma avaliação de argumentos científicos em particular, uma compreensão do estatuto de conhecimento científico específico, a forma pela qual este é gerado, comunicado e cuidadosamente analisado pela comunidade de cientistas e a medida de acordo com a qual ele pode ser mobilizado para informar decisões críticas sobre QSC. Os estudantes precisam saber o que constitui uma investigação bem planejada e uma conclusão com bom 
suporte argumentativo. Eles precisam da capacidade de interpretar relatórios, dar sentido a desacordos, avaliar declarações de conhecimento, examinar argumentos, distinguir entre fatos, argumentos e opiniões, fazer julgamentos sobre boa ciência, má ciência e não-ciência, detectar erros, preconceitos e interesses escusos, e assim por diante - tudo aquilo que nós viemos a conhecer como uma compreensão da NdC. (ALLCHIN, 2013; ERDURAN; DAGHER, 2014; HODSON, 2009)

Kolstø (2001) resume o conhecimento e a compreensão sobre NdC necessários para abordar QSC em termos de oito elementos principais:

- distinção entre ciência-em-construção (science-in-the-making), na qual a disputa, o desacordo e a incerteza são esperados, e a ciência pronta e acabada (ready-made science), em que podemos confiar;

- reconhecimento de que fatores socioculturais, políticos, econômicos e religiosos podem ter impacto sobre as prioridades para a pesquisa e o desenvolvimento científico e sobre as declarações de conhecimento que são aceitas;

- habilidade para avaliar a qualidade da evidência científica e estatística, e para julgar a adequação do conhecimento anedótico e do conhecimento experiencial;

- habilidade para avaliar o grau de apoio a uma declaração de conhecimento e a qualidade do argumento que estabelece a garantia para a crença;

- ter uma abordagem cética, ou seja, uma postura crítica, questionadora e um compromisso de resistir a tirar conclusões precipitadas até que evidências e argumentos adequados tenham sido reunidos;

- consciência da importância de fatores contextuais ao avaliar declarações de conhecimento, incluindo o estatuto social dos atores e de suas lealdades institucionais;

- sensibilidade para os valores, ideologias e potenciais para vieses subjacentes, no planejamento e na elaboração de relatórios de investigações científicas; e

- consciência dos constrangimentos que podem limitar a aplicação de conhecimentos teóricos generalizados a situações particulares do mundo real.

Uma simples lista de checagem pode ser extremamente útil para os estudantes que lêem relatórios de estudos de investigação específicos. Quem conduziu a pesquisa e onde ela foi realizada? Como a pesquisa foi financiada? Foi a pesquisa patrocinada e, em caso afirmativo, por quem? O que está sendo reivindicado? Que evidência apoia a reivindicação? Como a evidência foi coletada? Como a evidência foi interpretada? Que suposições são feitas e que teorias são utilizadas na argumentação a partir da evidência para a conclusão? Será que os autores usam teorias bem estabelecidas ou, ao invés, eles desafiam tais teorias? São possíveis interpretações e conclusões alternativas? Que 
evidência adicional ajudaria a esclarecer ou resolver as questões? Houve outros estudos realizados por estes cientistas, ou por outros?

\section{Questões de linguagem}

Se os estudantes devem abordar QSC cuidadosa e criticamente, eles precisam de uma compreensão robusta da linguagem científica e de como ela é utilizada na comunicação e na argumentação científica. A comunicação científica pode ser categorizada como:

- a comunicação entre os cientistas através de periódicos científicos e textos de conferências;

- a popularização e a divulgação do conhecimento gerado pela comunidade científica através de jornais, revistas, televisão e sites de internet; e

- a educação formal, através de livros didáticos e de outros materiais curriculares.

Temos de garantir que os estudantes desenvolvam habilidades de leituras proficientes e críticas para todos os três tipos de texto, ou seja, a capacidade de:

- determinar quando algo é uma observação, uma inferência, uma hipótese, uma conclusão ou um pressuposto;

- distinguir entre uma explicação e a evidência para ela; e

- reconhecer quando o autor está enunciando uma “verdade científica”, manifestando as suas dúvidas ou realizando uma especulação. Habilidades de leitura crítica precisam ser modeladas e ensinadas, cuidadosamente e de forma sistemática.

Especificamente, os alunos precisam de conselhos, críticas e apoio nos seus esforços para conectar elementos de informação dentro e através de textos, avaliar a validade e a confiabilidade de toda a informação utilizada, pesar os méritos das alternativas rivais, avaliar consistência e inconsistência e procurar resolver inconsistências, recolhendo mais informações. Eles precisam conhecer a forma, a estrutura e a linguagem dos argumentos científicos, o tipo de prova invocado e como esta prova é organizada e mobilizada, as formas nas quais a teoria é usada e o trabalho de outros cientistas é citado para fortalecer o argumento.

A necessidade de acessar informações de uma ampla variedade de fontes levanta a importante questão do letramento sobre mídia. ${ }^{2}$ (BURBULES; CALLISTER, 2000) Os

2 Alfabetização, literacia ou letramento sobre mídia é um assunto de extrema importância para a educação, como um todo, e para a educação científica, em particular. Ainda, no caso do Brasil, em particular, dado o constante e sistemático bloqueio que grandes veículos de comunicação exercem sobre questões políticas, sociais e ambientais de interesse social abrangente e até mesmo o viés indisfarçadamente político e propagandístico de grande parte do noticiário de tais veículos, é salutar 
estudantes que são letrados em mídia são capazes de acessar, compreender, analisar, avaliar, comparar e contrastar a informação de uma variedade de fontes, além de utilizar essa informação criteriosamente e de forma adequada para sintetizar sua própria visão detalhada do tópico ou da questão sob consideração. Eles podem reconhecer que a mobilização de linguagens, imagens, símbolos e sons particulares em uma apresentação multimídia pode, para cada uma delas, desempenhar um papel na determinação do impacto de uma mensagem e terá uma profunda influência sobre seu valor e sua credibilidade percebidos. Eles são capazes de verificar as intenções do escritor de determinar qualquer subtexto e significado implícito, detectar vieses e interesses escusos e distinguir entre, de um lado, informações boas e confiáveis e, de outro lado, aquelas pobres e não confiáveis. Eles estão alertas para o fato de que os especialistas dos meios de comunicação impressos, gráficos e falados usam vocabulários, gramáticas, sintaxes, metáforas e referências particulares, com o objetivo de capturar a nossa atenção, acionar nossas emoções, persuadir-nos de um ponto de vista e, em certas ocasiões, ignorar por completo as nossas faculdades críticas. Eles entendem que o material sob análise pode ser tendencioso e pode usar uma variedade de técnicas jornalísticas, tais como linguagem emotiva, hipérbole e insinuações, fotos e imagens provocadoras e música de fundo emocionalmente manipuladora, para persuadir os leitores, telespectadores e ouvintes de um ponto de vista particular. Para que os estudantes desenvolvam estas capacidades, é preciso haver um programa sistemático de instrução, prática, apoio e crítica.

\section{Ciência como uma prática social}

A ciência é uma prática social em dois sentidos distintos: em primeiro lugar, ela está localizada dentro de um ambiente social, político e econômico que tem grande impacto sobre as suas práticas e prioridades; em segundo lugar, ela é governada, dirigida e monitorada por decisões tomadas no seio da comunidade de praticantes. Em outras palavras, a prática da ciência é profundamente influenciada por forças sociais tanto externas quanto internas. No que diz respeito a forças externas, é importante para os estudantes que eles reconheçam que a ciência não é impulsionada apenas por sua própria lógica interna ou por uma simples busca da verdade; em vez disso, ela é motivada e moldada pelas necessidades, os interesses, as motivações, as crenças pessoais, os valores, as aspirações e atitudes políticas dos cientistas, os pontos de vista dos indivíduos, os grupos e organizações dispostos a fornecer o financiamento necessário e, ainda, a opinião pública. Necessariamente, ela reflete a história, a estrutura de poder e o clima político da co-

- a bem da própria democracia - que o professor de ciências utilize ampla variedade de meios de comunicação (por exemplo, TV, jornais, internet), sobretudo, fazendo uso de veículos alternativos à mídia hegemônica, como Mídia Ninja (Narrativas Independentes, Jornalismo e Ação; https:// ninja.oximity.com/), Estúdio Fluxo (http://www.fluxo.net/; https://www.youtube.com/user/estudiofluxo) e Agência Pública (Agência de Reportagem e Jornalismo Investigativo; http://apublica. org/). (N. do O.). 
munidade mais ampla na qual ela está inserida. Necessariamente, ela reflete as atitudes e os valores sociais, econômicos, políticos e ético-morais predominantes daquela comunidade. Em outras palavras, a ciência é, em grande parte, um produto do seu tempo e lugar. As palavras de Young (1987, p. 18-19) fornecem um resumo sucinto da situação:

Não há nenhuma outra ciência além daquela ciência que é feita. A ciência que existe é o registro das perguntas que ocorreram aos próprios cientistas, as propostas que foram financiadas, os caminhos que foram perseguidos [...] os assuntos que importam para uma dada sociedade, seu sistema educacional, o seu sistema de patrocínio e os seus órgãos de financiamento.

Vários pontos importantes seguem. Em primeiro lugar, o corpo do conhecimento científico existe como uma tradição, com uma história durante a qual muitos objetivos, atitudes e valores diferentes terão deixado uma marca. Segundo, para serem admitidas no corpus do conhecimento científico aprovado, as teorias têm que ser socialmente, culturalmente e politicamente aceitáveis, bem como cientificamente justificáveis. Terceiro, nós podemos e provavelmente devemos trazer "diferentes" objetivos, atitudes e valores para suportar futuras tomadas de decisão. Em quarto lugar, a ciência é tanto culturalmente dependente quanto culturamente transformadora, surgindo diretamente dos problemas que nós encontramos, as necessidades e os interesses que nós desenvolvemos e as perguntas que nós fazemos, e impactam muito direta e profundamente no tecido social, cultural e econômico da sociedade, incluindo a língua em que expressamos nossos pensamentos e as maneiras pelas quais conduzimos nossas vidas diárias.

É muito mais fácil para os estudantes reconhecerem como a tecnologia é determinada pelo contexto sociocultural em que ela está localizada do que ver como a ciência é conduzida por tais fatores e, ainda, é muito mais fácil que eles vejam o impacto ambiental da tecnologia do que as formas pelas quais a ciência impacta a sociedade e o meio ambiente. De fato, a tecnologia é por vezes definida como o meio pelo qual as pessoas modificam a natureza para satisfazer as suas necessidades e desejos e melhor servir aos seus interesses, moldando, assim, a vida das pessoas e das outras espécies e impactando de forma significativa sobre o meio ambiente como um todo. No mundo ocidental contemporâneo, a tecnologia é onipresente; o seu impacto social e ambiental é claro; as suas desconcertantes implicações sociais e seus perturbadores dilemas ético-morais são mostrados quase todos os dias através dos tabloides e noticiários de TV. Por estes tipos de razões, faz bastante sentido incluir QSC com forte presença das dimensões tecnológicas e de engenharia no currículo.

Voltando-nos para as dimensões sociais internas da ciência, necessitamos auxiliar os estudantes na apreciação de normas, valores e tradições internos que informam e dirigem a prática científica. Como uma série de procedimentos rigorosos e cuidadosamente monitorados, a ciência encarna um conjunto de valores: ordem, cuidado e precisão, atenção meticulosa e crítica, precisão, confiabilidade e replicabilidade. O co- 
nhecimento gerado por cientistas tem de obedecer a certos valores: clareza, coerência, universalismo, estabilidade, cautela e fecundidade (no sentido de resolver problemas e ter capacidade preditiva). Elegância, simplicidade e parcimônia também podem ser fatores significativos para a obtenção de apoio para uma teoria. Além disso, espera-se que os praticantes mostrem e pratiquem certos valores pessoais: objetividade, racionalidade, integridade intelectual, precisão, diligência, mente aberta (open-mindedness), autocrítica, ceticismo e prudência (no sentido de suspender o julgamento até que toda a evidência esteja em mãos). Adicionalmente, espera-se que eles sejam racionais. Questões críticas são feitas por outros praticantes sobre a adequação, o alcance e a precisão dos dados, como eles foram coletados e interpretados, e se as conclusões decorrem diretamente dos dados. A explicação é examinada com relação à sua consistência interna e também quanto à consistência com outras teorias aceitas. Atenção particular é dirigida para a teoria de fundo, para os pressupostos subjacentes ao planejamento da pesquisa e para a mobilização de teorias auxiliares, assim como para a escolha dos métodos de instrumentação e medição.

Uma vez que os estudantes reconheceram que a investigação científica é influenciada pelo contexto sociocultural em que ela está situada, o próximo e óbvio passo é direcionar a atenção dos estudantes para as formas nas quais a ciência e a tecnologia são influenciadas por determinados interesses setoriais e as maneiras pelas quais as normas e os valores da prática científica são, por vezes, subordinados aos interesses comerciais ou mesmo violados em busca deles. A intenção é ajudar os estudantes a olhar criticamente para o tipo de ciência e tecnologia em que nos envolvemos e os valores sociais, políticos, econômicos e ético-morais que orientam o desenvolvimento, e perguntar o que pode e deve ser alterado, a fim de alcançar democracias socialmente mais justas e assegurar estilos de vida ambientalmente mais sustentáveis. Este ponto de vista da educação científica é manifestada e assumidamente político. Ele, de todo o coração, endossa as opiniões expressas pelos autores da Education for citizenship and the teaching of democracy in schools. (QCA, 1998, p. 13, grifo nosso)

Não apenas a educação sobre cidadania, mas a educação para a cidadania [...] educação cidadã é educação para a cidadania, comportar-se e agir como um cidadão, portanto, não é apenas o conhecimento da cidadania e da sociedade civil; ela implica, também, o desenvolvimento de valores, habilidades e compreensão.

\section{Reconhecendo as dimensões políticas das QSC}

Em Hodson (2011), eu discuti o valor de uma abordagem que constrói a capacidade dos estudantes para a ação sociopolítica sobre QSC, através de um modelo de quatro estágios. 
- Estágio 1: a apreciação dos impactos sociais e ambientais da mudança científica e tecnológica e o reconhecimento de que a ciência e a tecnologia são, até certo ponto, culturalmente determinadas;

- Estágio 2: o reconhecimento de que as decisões sobre o desenvolvimento científico e tecnológico são tomadas na busca de interesses particulares e que benefícios para alguns podem ser às custas de outros. $\mathrm{O}$ reconhecimento de que os desenvolvimentos em ciência e tecnologia são inextricavelmente ligados à distribuição de riqueza e poder;

- Estágio 3: abordar a controvérsia, esclarecer valores, resolver dilemas éticos, formular e desenvolver suas próprias opiniões e justificá-las através da discussão e do argumento;

- Estágio 4: preparar-se para agir e agir sobre questões sociocientíficas e ambientais.

No estágio 4, estudos de caso de grandes inovações tecnológicas, tais como a máquina a vapor, o motor de combustão interna e/ou o computador, são ideais para traçar os fatores sociais e econômicos que impulsionam a inovação e para a sensibilização das maneiras em que a tecnologia molda as vidas das pessoas, impacta significativamente $\mathrm{o}$ ambiente e pode, às vezes, mudar muito radicalmente as formas como as pessoas pensam, falam e agem. Sobre este último ponto, os próprios estudantes têm vivido e experimentado as mudanças maciças trazidas pela tecnologia da computação e pelo desenvolvimento dos meios de comunicação social. Desenvolvimentos na engenharia genética têm questionado as nossas noções de vida e morte e os nossos pontos de vista sobre o que é natural e o que é artificial e tem nos apresentado profundos problemas ético-morais. Ambos os desenvolvimentos têm colocado grandes desafios para os nossos conceitos de liberdade, igualdade, democracia e identidade pessoal.

Estudos de casos bem escolhidos mostram aos estudantes que a inovação tecnológica é complexa, de grande alcance e não é totalmente previsível, às vezes trazendo benefícios ou custos inesperados e riscos imprevistos. Os benefícios das inovações científicas e tecnológicas são, por vezes, acompanhados de problemas: a necessidade urgente para muitas pessoas desenvolverem novas habilidades, mudanças sociais difíceis e, às vezes, desconcertantes, mudanças radicais no estilo de vida, riscos para a saúde humana, a degradação ambiental, os principais dilemas ético-morais e, às vezes, restrição, ao invés de ampliação, da liberdade e da escolha individual. As tecnologias quase sempre se desenvolvem mais rapidamente do que a nossa consciência dos problemas; do que nossa compreensão das questões éticas associadas e dos desenvolvimentos de restrições legais. A percepção de toda a extensão dos riscos, muitas vezes, vem muito tarde, como no caso do DDT (diclorodifeniltricloroetano) e dos CFCs (clorofluorcarboneto ou clorofluorcarbono). Significativamente, o impacto pode afetar principalmente aqueles com pouco ou nenhum poder para protestar, organizar contra-ações concertadas, demandar mudanças e/ou buscar compensações. Por estas razões, é importante assegurar que haja 
um escrutínio mais amplo e mais crítico de nossas políticas e prioridades para a investigação científica e o desenvolvimento tecnológico, assim como de um acompanhamento mais próximo de todos os ensaios e implementações por parte de um grupo mais diversificado de pessoas. É comum que o poder sedutor das tecnologias novas e poderosas nos cegue quanto a possíveis consequências adversas inesperadas e nos desvie da consideração dos valores que as acompanham. Mais preocupante ainda, os riscos podem ser conhecidos, mas eles são ignorados, porque é mais conveniente manter o status quo e esperar que os problemas desapareçam ou que sejam resolvidos por novas descobertas científicas ou inovações tecnológicas.

Inovações em Tecnologias da Informação e da Comunicação (TIC), como os telefones celulares, correios eletrônicos (e-mail) e a internet, criaram oportunidades, possibilidades e perigos que seriam inimagináveis há duas décadas. Tecnologias baratas, leves e portáteis mudaram, ampliaram, fragmentaram e redefiniram a base do poder das comunicações, e mostraram que os governos, as Organizações não Governamentais (ONG), as grandes corporações financeiras e o setor militar já não podem mais explorar a ignorância pública ou exercer controle absoluto sobre as notícias e as informações. Já não há mais um abismo de tempo entre um evento e o surgimento de um registro do próprio evento, durante o qual a história pode ser editada e manipulada para refletir interesses particulares. Dentro de minutos, o público tem acesso às impressões vívidas e autênticas do que está acontecendo, até mesmo em partes remotas do mundo. Não há mais tempo para que os governos e outras partes interessadas se antecipem, mediem ou suprimam informações. Porque essas novas tecnologias portáteis estão disponíveis para quase todos, uma nova capacidade de escrutínio imediato e um concomitante chamado por uma maior responsabilização surgiu, como graficamente ilustrado pelo episódio de Freddie Gray, em Baltimore, Estados Unidos. ${ }^{3}$ Novos modos de desenho das comunicações criaram um espaço para políticas, culturas e vozes alternativas e criaram novas oportunidades para a intervenção coletiva para abordar questões e problemas comuns. Ao mesmo tempo, no entanto, eles têm aumentado substancialmente a capacidade dos empregadores e governos para monitorar as comunicações e atividades de empregados e cidadãos, criando alguns dos principais problemas de privacidade e propriedade. Devido à atribuição de códigos numéricos rastreáveis às mensagens de e-mail, quase qualquer mensagem pode ser rastreada e disponibilizada para outras pessoas, possivelmente em forma modificada, como as revelações de Edward Snowden têm mostrado. ${ }^{4}$

3 Nota dos organizadores: em particular, no caso do Brasil, por exemplo, os vídeos da Mídia Ninja, site mencionado na nota 2, oferecem acesso bastante direto a eventos de interesse político, sejam regionais ou nacionais. A cobertura e as interpretações ágeis de tais veículos alternativos de comunicação, como ocorreu nas Jornadas de Junho de 2013 ou noutras manifestações políticas mais recentes, nas ruas do Brasil contemporâneo, oferecem uma boa ilustração do ponto levantado pelo autor. Ver link: <www.democracynow.org $>$.

4 Veja em: <www.democracynow.org $>$ ou em $<$ www.theguardian.com $>$. 
No estágio curricular 2, o objetivo é ajudar os estudantes a reconhecer que as decisões científicas e tecnológicas são normalmente tomadas na busca de interesses particulares, justificadas por valores particulares e, às vezes, implementadas por aqueles com o poder econômico ou político para sobrepujar as necessidades e os interesses dos outros. Consequentemente, os estudantes devem ser encorajados a perguntar uma série de questões-chave sobre cada inovação científica ou tecnológica. Por que esta investigação científica, em particular, foi financiada e esta tecnologia foi perseguida? Qual é a lógica e qual a justificativa subjacentes para essas decisões? Quais são os efeitos sociais, econômicos e ambientais percebidos? Quais são as questões ético-morais levantadas e quais são os prováveis impactos adversos? Quem são os principais atores envolvidos? Quais são os seus interesses? As vozes de quem são ouvidas e as de quem são marginalizadas ou ignoradas? Que intenções ou motivos orientam a tomada de decisão? Quem se beneficia? Quem é prejudicado? Isto é justo e equitativo? Será que esta decisão promove o bem comum e serve às necessidades de proteção ambiental? Devemos apoiar ou nos opormos a este desenvolvimento? Respostas a estas perguntas, muitas vezes, revelam que a ciência e a tecnologia servem aos ricos e aos poderosos de maneiras que são prejudiciais para os interesses e bem-estar dos pobres e desempoderados, às vezes, dando origem a mais desigualdades e injustiças. Por exemplo, o lixo resultante do consumo urbano, nos países ocidentais, é enviado para instalações de incineração, depósitos e aterros localizados predominantemente em comunidades urbanas e rurais de maior pobreza e desvantagem social. Os ricos podem reduzir o seu próprio nível de risco e exposição ao efluente tóxico mudando de casa; os politicamente poderosos podem fazê-lo garantindo que a instalação seja situada em outros lugares; os mais pobres e os mais fracos são expostos aos perigos e têm de sofrer os problemas. De uma perspectiva internacional, torna-se rapidamente claro que os benefícios materiais do Ocidente (Norte) são muitas vezes conseguidos às custas daquelas pessoas que vivem no mundo em desenvolvimento (Sul), com um estilo de vida orientado para o consumo das nações industrializadas, criando ambientes contaminados que impactam desproporcionalmente sobre aqueles menos capazes de se proteger. Por exemplo, como Agyeman e Carmin (2011) e Bisschop (2014) relataram, grande parte do lixo eletrônico gerado na União Europeia é exportado para depósitos de lixo na África Ocidental, no Sudeste Asiático e na Índia, onde muitas vezes é desmontado por catadores e trabalhadores mal equipados, incluindo muitas crianças, em busca de sucata de metal. O restante do material é, geralmente, queimado ou despejado em locais desprotegidos, resultando em contaminação substancial do ar, da água e do solo por chumbo, cádmio, ftalatos e dioxinas cloradas - todos com propriedades cancerígenas e impactos neurológicos adversos. (GREENPEACE, 2008)

A frequência com que a degradação ambiental impacta os pobres, desfavorecidos, marginalizados e desempoderados muito mais do que os ricos e poderosos justifica o uso do termo "racismo ambiental". Por exemplo, as substâncias consideradas perigosas para o ambiente, e, portanto, proibidas em países ricos do Norte, ainda são exportadas 
para países em desenvolvimento no Sul, economicamente mais vulneráveis (MARTINEZ-ALIER, 2003), enquanto que os produtos farmacêuticos proibidos nos países industrializados são vendidos, distribuídos e utilizados, frequentemente, nos países em desenvolvimento, porque eles são rentáveis para os fabricantes. Resíduos altamente tóxicos são rotineiramente enviados da Europa e dos Estados Unidos, onde são criados, para países pobres, como Guiné-Bissau e Serra Leoa, em troca de ajuda econômica. (BROOKE, 1988; IBITAYO, 2008) Por muitos anos, instalações industriais, localizadas ao longo da fronteira Estados Unidos e México (conhecidas localmente como maquiladoras), rotineiramente despejam resíduos tóxicos em esgotos e rios, inclusive, aqueles nos quais as comunidades locais obtêm sua água potável. Nas cidades fronteiriças de Brownsville (Texas) e Matamoras (México), a incidência de crianças que nascem com anencefalia, ou seja, nascidos sem o prosencéfalo, é quatro vezes a média nacional. Bullard e Johnson (2000) relatam que famílias afetadas apresentaram ações judiciais contra 88 das 100 maquiladoras da área por terem exposto a comunidade ao xileno - considerado a causa desses defeitos de nascença e conhecido por causar hemorragias cerebrais, assim como danos aos pulmões e rins. Mais informações sobre os danos à saúde humana e a problemas ambientais relacionados às maquiladoras podem ser encontradas em Rai e Norton (2007).

Outras questões dizem respeito ao papel desempenhado pelos governos ocidentais e os interesses das empresas no controle da produção e da distribuição de recursos nos países em desenvolvimento, incluindo exemplos de apropriação sistemática dos recursos da terra e da água para a produção de culturas de alto rendimento para exportação para os países mais industrializados, muitas vezes, resultando em: preços mais baixos para os agricultores; aumento da vulnerabilidade das culturas a pragas (e um consequente aumento da dependência de controles químicos); empobrecimento do solo e esgotamento do solo superficial; aumento de pobreza, insegurança e eventuais desapropriações. Os países em desenvolvimento são muitas vezes obrigados a aceitar as tecnologias e práticas agrícolas dos países desenvolvidos ou mais industrializados, incluindo o amplo uso de fertilizantes, para aumentar o rendimento das culturas; herbicidas e inseticidas, para plantas daninhas e controle de pragas; agricultura mecanizada e práticas de irrigação; e até mesmo a adoção de culturas geneticamente modificadas, em troca de outras formas de ajuda econômica e apoio militar. Tais insumos de alto custo podem não ser economicamente acessíveis ou ecologicamente sustentáveis. Chopra (2009) descreve como a introdução dos métodos do agronegócio dos países desenvolvidos - incluindo o uso generalizado de fertilizantes químicos, agrotóxicos, hormônios de crescimento e antibióticos; o extenso desmatamento; a introdução de plantas e animais geneticamente modificados; e a reutilização dos rejeitos de matadouros para a alimentação dos animais - teve um impacto ecológico desastroso em muitas partes da Índia. O lençol freático caiu para níveis alarmantemente baixos; a população de minhocas foi devastada, com grande impacto negativo sobre a qualidade do solo superficial; muitas 
espécies de abelhas, borboletas e pássaros, essenciais para o processo de polinização, estão em sério declínio; bactérias fixadoras de nitrogênio estão quase extintas; e os números de animais insetívoros, tais como sapos e lagartos, estão muito reduzidos, com o consequente declínio do número de predadores que se alimentam deles (águias, falcões etc.) e dos abutres que se alimentam das "sobras". Igualmente desastroso tem sido o impacto negativo sobre a vida de agricultores de subsistência.

\section{Abordando questões controversas}

O estágio curricular 3 centra-se em apoiar os estudantes em suas tentativas de formular suas próprias opiniões sobre questões importantes e frequentemente controversas e, ainda, estabelecer as suas próprias posições de valor. Este estágio também envolve empenhar-se na luta para estabelecer práticas socialmente mais justas e ambientalmente mais sustentáveis e construir a confiança, a mentalidade, os insights e habilidades necessários para uma defesa e uma agência a favor de mudanças efetivas e responsáveis. O trabalho em tal estágio concentra-se no esclarecimento dos valores, no desenvolvimento de fortes sentimentos sobre questões sociais e em pensar ativamente sobre o que significa agir sábia, justa e "corretamente" em contextos sociais, políticos e ambientais particulares. A educação em tal estágio tem muito em comum com os objetivos de educação para a paz, educação multicultural e antirracista, educação global e educação humanitária. Ela começa com a promoção da autoestima e do bem-estar pessoal, acolhendo e escutando a uma diversidade de ideias, opiniões, perspectivas, práticas e valores; preocupações com o bem-estar dos outros; o respeito aos direitos dos outros; a construção de empatia e confiança mútua; a busca de justiça, equidade e liberdade, tomadas de decisão cooperativas, resoluções criativas de divergências e conflitos entre as pessoas, dentro e entre as comunidades e em todo o mundo. Ela é dirigida por um profundo compromisso com a educação antidiscriminatória, isto é, aquela educação que expõe as raízes comuns do sexismo, do racismo, da homofobia, do especismo, do eurocentrismo e dos vieses do Ocidente (ou do Norte) na tendência a dicotomizar e gerar uma sensação de outro ou de alterização e de trabalhar ativamente para enfrentar a mentalidade focada em uma diferença entre "nós e eles", a qual, invariavelmente, vê a "nós" como a norma, o desejável e o superior. Ela culmina em um compromisso com a crença de que vozes alternativas podem e devem ser ouvidas, a fim de que as decisões em ciência e tecnologia reflitam sabedoria e justiça, em vez de interesses setoriais poderosos.

A controvérsia pode ser interna à ciência, isto é, a informação científica necessária para formular um juízo sobre ela é incompleta, insuficiente, inconclusiva ou extremamente complexa e difícil de interpretar, ou pode ser externa à ciência, ou seja, enraizada em preocupações, crenças, valores e sentimentos sociais, políticos, econômicos, culturais, religiosos, ambientais, estéticos e/ou ético-morais. A capacidade de resolver a controvérsia interna depende crucialmente dos conhecimentos e habilidades de leitura 
crítica dos estudantes sobre $\mathrm{NdC}$, como discutido acima; a capacidade e a vontade para resolver as controvérsias externas dependem de uma análise cuidadosa das emoções, dos sentimentos, e de questões ético-morais e/ou posição política.

Uma vez que uma decisão foi tomada, para incluir questões externamente controversas no currículo, os professores têm de decidir a forma mais adequada para resolvê-las. Deveriam eles tomar uma posição neutra, adotar o papel de advogado do diabo ou tentar apresentar uma visão equilibrada? Uma forma de neutralidade, a neutralidade afirmativa, descreve uma situação em que os professores apresentam vários lados de uma controvérsia sem revelar que lado eles suportam. Na neutralidade procedimental, as informações sobre a controvérsia e os diferentes pontos de vista são solicitados aos estudantes, possivelmente após oportunidades para pesquisa em bibliotecas ou na internet. Para além do perigo de incentivar o relativismo, no qual qualquer ideia é aceita, desde que ela seja a opinião de alguém, a neutralidade é uma posição que ameaça seriamente a credibilidade do professor e convida a uma pergunta razoável: você não tem um ponto de vista, senhorita/senhor? É um absurdo fingir que os professores não têm um ponto de vista; é lamentável que os professores se recusem a enunciar sua opinião ao mesmo tempo em que encorajam ou até mesmo exigem que os estudantes apresentem as suas. A noção de imparcialidade ou de apresentar uma visão supostamente equilibrada também é extremamente problemática. O que conta como equilíbrio? O julgamento de equilíbrio e a seleção de perspectivas de quem deve contar? Quem decide o que conta como relevante ou não relevante, preciso ou impreciso, admissível ou inadmissível, importante ou não importante? Quem decide o que deve ser considerado fato e o que deve ser considerado opinião? Se todos os estudantes expressam uma visão semelhante, de onde virão os pontos de vista alternativos? A noção de imparcialidade exige que os professores dêem tempo, consideração, assim como pesos iguais, aos pontos de vista e aos argumentos que claramente não são de igual mérito e impede os estudantes de desenvolverem as habilidades críticas necessárias para julgar o valor e a validade das diferentes posições. Alguns anos atrás, Kelly (1986) defendeu a imparcialidade comprometida (committed impartiality), em que os professores apresentam vários lados de uma questão ou argumento e, em algum momento, partilham os seus próprios pontos de vista com a classe. Em minha opinião, é fundamental que os professores ajudem os estudantes a identificar, a esclarecer e a desafiar os pressupostos de todas as posições (incluindo a sua própria), reconhecer a influência do contexto sociocultural, crenças religiosas, emoções e sentimentos, abordar questões de racionalidade, equidade e justiça social e se envolver em reflexão crítica em grupos. Quando os estudantes são encorajados a debater e a desafiar todos os pontos de vista, incluindo o do seu professor, eles não apenas desenvolvem habilidades de argumentação, mas também constróem a coragem essencial para o compromisso social. ${ }^{5}$

5 Neste parágrafo, o autor discute uma questão muito importante para a educação pública no Brasil atual: a discussão de assuntos com teor ético e político nas salas de aula. Em especial, aqui merece 
Algumas QSC estão distantes das vidas imediatas dos alunos, tornando difícil a geração de interesse, preocupação e compromisso para/em desafiar o status quo. Filmes, histórias, teatro, dramatização, poesia, materiais multimídia e atividades baseadas na linguagem, de vários tipos, podem ser usados para estimular o interesse em uma questão, provocar uma resposta emocional, apresentar posições alternativas, desafiar valores e precipitar o debate. Histórias justapõem diferentes opiniões, vozes e perspectivas, estimulando o leitor (ou ouvinte) a deliberar, avaliar e decidir sobre onde eles estão ou adotar uma postura diferente. Através de histórias e, especialmente, através do teatro, os estudantes são estimulados a abordar questões e eventos a partir das perspectivas dos outros, explorar e desenvolver a compreensão, estabelecer novas relações e consolidar as já existentes. Em outras palavras, envolver-se com a narrativa é tanto uma forma de conhecer a nós mesmos, como também uma forma de compreender os pontos de vista dos outros. $\mathrm{O}$ teatro improvisado permite aos estudantes enriquecer essas explorações com experiências pessoais, pensamentos e preferências linguísticas. Incentivar os estudantes a escrever poesia e histórias cria oportunidades para eles explorarem as suas ideias, expressá-las em linguagem menos formal, manipulá-las e criticá-las, colocando-as na boca dos outros, explorar a ambiguidade e a incerteza, enfrentar dilemas e, crucialmente, expressar a maneira como eles se sentem com relação às suas ideias e às ideias dos outros.

A discussão sobre QSC não apenas levanta questões sobre o que nós "podemos" ou "poderíamos" fazer, mas também sobre qual é a decisão "certa" e o que "devemos" fazer, desta forma, levantando algumas dimensões éticas centrais. Os desenvolvimentos recentes na biotecnologia, por exemplo, levantam muitas questões e preocupações importantes sobre se determinadas linhas de pesquisa devem ser permitidas. Um indivíduo com uma condição genética incapacitante deveria estar apto a ser submetido à terapia gênica, utilizando o material a partir de células-tronco embrionárias? Os testes genéticos pré-natais deveriam estar prontamente disponíveis e o aborto seletivo de um feto com uma doença genética deveria ser permitido? Os pais já podem escolher o sexo de seu filho; em breve, poderá ser possível isolar e remover genes que aumentam a probabilidade de esquizofrenia, obesidade, alcoolismo, Transtorno do Déficit de Atenção e Hiperatividade (TDAH) e de uma série de condições letais ou incapacitantes. Esta engenharia genética deveria ser permitida? Talvez seja possível, em breve, para os futuros pais, escolher a cor do cabelo e dos olhos de uma criança ou selecionar quaisquer outras características que considerem desejáveis. Estas ações iriam colocar valor em um tipo de pessoa em detrimento de outro - isto é, uma intenção eugenista clara. Isso deve ser

menção o movimento autointitulado "Escola Sem Partido", vinculado a alguns projetos de lei do Congresso nacional brasileiro e que ameaça a liberdade dos próprios professores, para ensinar, e a qualidade da educação do país como um todo. Para mais detalhes sobre o assunto, pode-se consultar: <https://liberdadeparaensinar.wordpress.com/> e <https://liberdadeparaensinar.wordpress. com/category/carta-de-repudio/>. (N. do O.). 
permitido? Deve haver restrições sobre o trabalho de Craig Venter, que desloca o foco da leitura de um código genético para escrever um código genético - isto é, não apenas modificar um organismo já existente para garantir "características mais favoráveis", mas construir um totalmente novo. ${ }^{6}$

Determinar a resposta certa (o que nós devemos fazer) levanta questões e preocupações sobre a moralidade (o que é certo ou errado fazer) e a ética (as razões e justificativas para julgar essas ações como certas ou erradas). Eu certamente não estou argumentando que os estudantes devam seguir um curso rigoroso de filosofia moral, não mais do que eu defenderia quanto à promoção de uma moralidade baseada em uma religião em particular ou em um conjunto de leis e precedentes culturais, mas eu defendo que eles sejam equipados com algumas ferramentas intelectuais para enfrentar e resolver questões polêmicas, que não podem ser resolvidas unicamente por considerações científicas, econômicas ou ambientais. No mínimo, os estudantes precisam de algum conhecimento básico acerca do egoísmo, das noções consequencialistas (incluindo o utilitarismo), da ética deontológica, da teoria do construto social (ou teoria do contrato social) e da ética das virtudes. (BONJOUR; BAKER, 2007; HURSTHOUSE, 1999; SINGER, 1991)

Fullick e Ratcliffe (1996) descrevem uma série de estratégias que podem ajudar a dirigir a atenção dos estudantes às preocupações éticas presentes nas QSC e ajudá-los a lidar com dilemas éticos de uma forma sistemática e racional. As estratégias incluem:

- construção de árvores de decisão ou de cenários futuros (através dos quais os estudantes são convidados a considerar uma série de implicações pessoais, sociais, econômicas, legais, ambientais e éticas em torno de uma questão e das possíveis respostas a ela);

- frameworks sobre objetivos, direitos e deveres (goals, rights and duties frameworks) (para cada participante ou setor envolvido em uma polêmica, os estudantes consideram as intenções, os direitos/expectativas e as obrigações em relação aos outros e ao meio ambiente); e

- grupos de discussão sobre questões cuidadosamente focadas (questões orais ou escritas dirigem a atenção dos estudantes para a natureza do problema, as soluções possíveis, as razões por que uma solução pode ser preferível a outra, e estimulam a reflexão sobre as posições de valor dos próprios estudantes).

O Centro de Aprendizagem em Biotecnologia da Nova Zelândia ${ }^{7}$ fornece suporte para os estudantes abordarem questões éticas na forma de duas ferramentas interativas de pensamento. A ferramenta de raciocínios em ética (ethics thinking tool) permite que

6 Ver em: <www.jcvi.org $>$ e $<w w w . t i g r . o r g>$.

7 Ver em: <www.biotechlearn.org.nz>. 
os estudantes estruturem e avaliem suas ideias em relação a quatro conjuntos de diretrizes/orientações éticas: benefícios e malefícios; direitos e responsabilidades; liberdade de escolha; virtudes. A ferramenta de raciocínios sobre os cenários futuros (futures thinking tool) encoraja os estudantes a considerar a situação existente, analisar as tendências, identificar as forças motrizes e as causas dessas tendências, identificar possíveis e prováveis futuros e selecionar futuros preferenciais.

A pesquisa sobre células-tronco coloca toda uma série de problemas éticos sobre os quais os estudantes podem exercitar suas habilidades em desenvolvimento. (FRANCE; MORA; BAY, 2012; HALVERSON; SIEGEL; FREYERMUTH, 2009) Em primeiro lugar, uma importante distinção pode ser estabelecida entre, de um lado, células-tronco adultas, derivadas do sangue, da medula óssea, da gordura e dos outros tecidos e, de outro, células-tronco embrionárias de culturas descartadas de Fertilização in Vitro (FIV), fetos abortados ou de embriões criados em laboratório. As células-tronco embrionárias são mais abundantes e mais fáceis de extrair; elas podem ser cultivadas e multiplicadas no laboratório mais facilmente; elas são mais flexíveis e, por isso, têm muito mais potencial regenerativo. Em resumo, elas são de valor muito maior em pesquisas e mais prováveis de resultar no desenvolvimento de tratamentos médicos inovadores. No entanto, para algumas pessoas, a distinção entre as células-tronco embrionárias e as células-tronco adultas também constitui uma fronteira entre a prática eticamente aceitável e a eticamente inaceitável. Para outros, o limite pode estar na distinção entre células-tronco de descartes de FIV e aquelas dos embriões clonados especificamente para fins de pesquisa. Aqueles que estabelecem a distinção ética neste momento argumentam que o uso de células a partir de embriões que sobram de tratamentos de FIV, que de outra forma seriam destruídos, é substancialmente menos condenável do que a clonagem de um embrião, a fim de colher suas células e depois destruí-lo. Em última análise, o debate gira em torno da questão filosófica sobre o que constitui um ser humano e a questão ética acerca dos direitos de quem deve ter prioridade. A vida humana começaria no ponto da concepção, no momento da implantação no útero, no início do processo de desenvolvimento, no ponto em que uma espinha dorsal e órgãos começam a se desenvolver ou no momento em que o feto é capaz de sobreviver fora da mãe, com ou sem apoio tecnológico sofisticado? Esses problemas são muito mais complexos do que a questão dos direitos relativos da mãe e do feto, que os estudantes terão que (ou poderão) abordar na discussão do aborto.

Em uma questão estreitamente relacionada à agricultura, os estudantes podem ser solicitados a considerar por que a utilização de plantas geneticamente modificadas está sendo amplamente promovida por empresas multinacionais como a Monsanto. (KNIGHT, 2009) Será que é porque a produção agrícola não pode ser mantida em níveis necessários para satisfazer as necessidades nutricionais da população mundial em crescimento? Será que é porque grande parte da colheita anual é perdida para as pragas e doenças que as plantas geneticamente modificadas podem ser desenhadas para resistir? 
Ou seria porque a dependência crescente de agricultores com relação às plantas geneticamente modificadas está nos interesses financeiros das companhias que mantêm as patentes? Os estudantes podem ser convidados a considerar os riscos ambientais que inevitavelmente resultariam da perda de riqueza e variância genética e se esses riscos devem ser tomados sem consulta pública mais ampla. Eles podem olhar para a possibilidade de riscos imprevistos, particularmente mutações e extinções decorrentes de interações de plantas geneticamente modificadas com insetos e outras plantas. No que diz respeito à avaliação dos riscos, os estudantes podem considerar a eficácia provável de protocolos para garantir que os riscos ambientais associados à introdução de organismos transgênicos sejam minimizados. Eles podem considerar quem fixaria os procedimentos e normas e se é provável que os protocolos sejam fielmente executados e monitorados por todos os agricultores. Obviamente, os métodos-padrão de avaliação de riscos não abordam os riscos sociais em torno da monopolização do abastecimento de alimentos do mundo nas mãos de uma ou duas empresas gigantes e o empobrecimento e o deslocamento das comunidades agrícolas de pequena escala, mas estas são considerações importantes para serem apresentadas aos estudantes.

Além disso, sobre questões de saúde, pode-se solicitar aos estudantes que considerem por que as empresas farmacêuticas consistentemente recusam-se a participar da pesquisa e do desenvolvimento orientados para o combate e o tratamento de doenças como a malária, a tripanossomíase (doença do sono) e a esquistossomose (bilharziose), enquanto destinam recursos maciços para a pesquisa sobre as doenças cardíacas e o câncer. A atenção dos estudantes deve ser dirigida para as formas em que os interesses comerciais, muitas vezes, influenciam o modo como os resultados da pesquisa são tornados públicos (conferências de imprensa, em vez de publicação em revistas acadêmicas, por exemplo) e os modos pelos quais o impacto dos dados negativos é minimizado, marginalizado, escondido ou ignorado. Por exemplo, na divulgação do valor de contraceptivos orais e terapia de reposição hormonal, o aumento dos riscos de câncer cervical, câncer de mama e tromboembolismo recebem, muitas vezes, pouca atenção. Seguindo o exame crítico de 70 artigos de pesquisa voltados para os Bloqueadores dos Canais de Cálcio (CCB), do inglês calcium channel blockers, utilizados para tratar a hipertensão, Stelfox e colaboradores (1998) concluíram que havia uma forte associação entre opiniões dos autores sobre a segurança dos CCB e as suas relações financeiras com fabricantes de produtos farmacêuticos. Táticas desleais, por vezes, vão muito além de manipulação da opinião pública através da imprensa. Por exemplo, em 2001, a Farmacêutica TAP foi multada em 875 milhões de dólares por fraude na assistência médica em relação ao seu medicamento anticâncer Lupron. Angell (2004) relatou que as acusações para as quais a TAP se declarou culpada incluíam subornar médicos com televisores, videocassetes, viagens para resorts, dinheiro sob a forma de "bolsas de estudo" (para ser usado para qualquer finalidade) e medicamentos gratuitos ou com grandes descontos, para que os médicos fossem encorajados a cobrar o 
Medicare pelo preço comercial total. ${ }^{8}$ Em setembro de 2009, a Pfizer foi multada em 2,3 bilhões de dólares por fornecer recompensas financeiras e outros incentivos para encorajar os clínicos gerais a prescrever medicamentos para usos não aprovados pelo Foods and Drugs Administration (FDA), ${ }^{9}$ principalmente, o uso do Bextra, uma droga desenvolvida para tratar a artrite, sendo prescrita como um analgésico geral. Curiosamente, a droga foi agora completamente retirada de uso. Outras acusações são aquelas relacionadas ao uso indevido da droga antipsicótica Geodon, do antibiótico Zyvox e da droga Lyrica, para tratamento da epilepsia. Em 2012, a GlaxoSmithKline (GSK) foi multada em 3 bilhões de dólares por subornar médicos e incentivar a prescrição de antidepressivos inadequados (Paxil) para crianças. No ano seguinte, a empresa incorreu em uma penalidade de 229 milhões de dólares pela comercialização indevida de um medicamento para diabetes (Avandia) e, em 2014, incorreu em outra de 490 milhões de dólares após a admissão de uma acusação de subornar médicos chineses para prescrever produtos da GSK.

\section{Agindo}

O estágio final (quarto), nesta abordagem baseada em questões, preocupa-se com os estudantes, buscando maneiras de colocar seus valores e convicções em ação, ajudando-os a preparar-se para (e se envolver em) uma ação responsável; e, ainda, ajudá-los no desenvolvimento de habilidades, atitudes e valores que irão permitir-lhes tomar o controle de suas próprias vidas, cooperar com os outros para realizar a mudança e trabalhar em direção a um mundo mais justo e sustentável, no qual o poder, a riqueza e os recursos são mais equitativamente partilhados. Não é o suficiente que os estudantes aprendam que ciência e tecnologia são influenciados por forças sociais, políticas e econômicas; eles precisam aprender como participar e eles precisam experimentar a participação. Além disso, eles precisam encorajar outros a participar: pais, avós, amigos, parentes, vizinhos e empresas locais. Não é o suficiente que estudantes sejam críticos de sofá! Assim, como Kyle Jr. (1996, p. 1) coloca:

A educação deve ser transformada da orientação passiva, técnica e apolítica, que é o reflexo de experiências baseadas na escola da maioria dos estudantes, para um esforço ativo, ao longo da vida, crítico e politizado, que transcende as fronteiras das salas de aula e das escolas.

8 Medicare é o sistema de seguros de saúde gerido pelo Governo Federal dos Estados Unidos (N. do O.).

9 FDA é o órgão governamental dos Estados Unidos responsável pelo controle dos alimentos, suplementos alimentares, medicamentos, cosméticos, equipamentos médicos, materiais biológicos e produtos derivados do sangue humano. Ver em: <www.fda.gov $\rangle$. (N. do O.). 
Com isso em mente, tenho muita simpatia pela noção de cidadão científico radical de Elam e Bertilssons (2003, p. 245):

O cidadão científico radical está totalmente preparado para participar em manifestações [...] marchas de rua, boicotes e resistências pacíficas e outros meios de confrontar publicamente aqueles que governam sobre ciência e tecnologia [...] Enquanto o cidadão científico como ativista pode tomar uma posição em defesa de um determinado indivíduo ou grupo na sociedade, eles também são entendidos como assumindo uma postura moral em defesa de princípios ético-políticos gerais [...] que são aceitos como existindo através de muitas interpretações diferentes e conflitantes [...] e sujeitando-os a uma contestação contínua.

Os estudantes irão tornar-se ativistas se eles se sentirem pessoalmente empoderados para efetuar a mudança, acreditarem que eles podem fazer a diferença e saber como fazê-lo. Além disso, a probabilidade de os estudantes se tornarem cidadãos ativos aumentará substancialmente, por meio do encorajamento destes a agirem agora (na escola), proporcionando oportunidades para que eles o façam e fornecendo exemplos detalhados de ações bem-sucedidas e intervenções desenvolvidas pelos outros. Ações apropriadas incluem: fazer declarações públicas; construir websites e boletins informativos; escrever para jornais; organizar petições e reuniões da comunidade; trabalhar para grupos locais de ação e coletivos de ação civil (citizen working groups); fazer cartazes; distribuir folhetos; protestar; produzir materiais multimídia informativos para a educação pública; divulgar conselhos aos proprietários de imóveis, agricultores e indústrias locais sobre a eliminação segura de resíduos tóxicos; estabelecer iniciativas, como a de um observatório da natureza (Nature Watch); instituir programas de reciclagem de vidro, papel e latas de alumínio; organizar boicotes de consumidores de produtos e práticas ambientalmente inseguros; trabalhar em projetos de limpeza ambiental (clean-up); criar trilhas naturais, lagoas de conservação e jardins de borboletas; plantar árvores; construir uma horta comunitária; criar um programa de almoço livre que não produza lixo; assumir a responsabilidade pela melhoria ambiental do terreno da escola (incluindo plantio de espécies indígenas e incentivo da biodiversidade); monitorar o consumo dos recursos energéticos e materiais da escola, a fim de formular práticas mais adequadas (incluindo o uso de painéis solares, por exemplo); reduzir o consumo de água por meio de planos de reciclagem; monitorar a utilização e a eliminação de materiais potencialmente perigosos dentro da escola; criar uma rede de compras verde; e assim por diante.

Às vezes, é útil distinguir entre ação direta e ação indireta. A primeira inclui coisas como a reciclagem, a limpeza de um riacho ou uma praia, usar uma bicicleta em vez de um carro ou de ônibus, desligar as luzes e usar sacos ou sacolas reutilizáveis e recicláveis no supermercado; enquanto a segunda inclui a compilação de petições, a distribuição de folhetos, escrever para jornais e fazer submeter propostas às auto- 
ridades locais. Enquanto a ação direta pode ser extremamente importante e pode ter algum impacto significativo, pode também desviar a atenção das causas do problema em consideração. Ela falha em não enfrentar as causas e os agentes reais da degradação ambiental, evita crítica e questionamento de nossas atividades sociais, políticas e econômicas. Em outras palavras, ela despolitiza os problemas e transfere o ônus da responsabilidade para indivíduos e famílias e está longe de governos, das corporações e das políticas que podem ter impacto significativo e a longo prazo, assim como das negociações políticas que podem levar à mudança. A limpeza de uma praia terá efeitos imediatos benéficos, é claro, mas sem uma investigação das causas e uma intervenção adequada destinada a essas causas não haverá solução duradoura. A criação de um programa de reciclagem pode prolongar a vida ativa de um ou dois aterros, mas não trata (e certamente não muda) a economia insustentável de uso, produção e consumo dos recursos naturais. Investigar os níveis de poluição do nitrato e do fosfato nos cursos de água é uma atividade importante; boicotar produtos agrícolas baseados em agrotóxicos e promover o uso de fertilizantes orgânicos pode ter mais impacto sobre o meio ambiente; realizar uma análise dos cursos de água, divulgando os dados dela decorrentes, identificar a causa provável da poluição, como o escoamento a partir de fazendas e parques locais, alertando os agricultores, o pessoal de manutenção do solo em instalações desportivas, os guardas do parque, assim como jardineiros domésticos para as causas e o impacto ambiental adverso de agrotóxicos, tornando-os conscientes de alternativas orgânicas, e incentivar os fornecedores agrícolas e centros de jardinagem para promover essas alternativas orgânicas é o ideal.

Preparar os estudantes para a ação necessariamente significa garantir que eles ganhem uma compreensão clara de como as decisões são tomadas dentro do governo local, regional, nacional e, ainda, dentro de vários grupos sociais, indústria, comércio e do setor militar. Sem o conhecimento de onde e com quem o poder de tomada de decisão está localizado e uma conscientização dos mecanismos pelos quais as decisões são alcançadas, a intervenção não é possível. Os estudantes precisam identificar as possibilidades de ação, avaliar a sua viabilidade e adequação, verificar restrições e barreiras, resolver as divergências entre aqueles que estarão envolvidos, olhar mais de perto as ações tomadas por outros (e o quanto elas têm sido bem sucedidas) e estabelecer prioridades em termos de quais ações são mais urgentes (e podem ser realizadas rapidamente) e que ações são necessárias a longo prazo. É essencial, também, que todas as ações tomadas pelos estudantes sejam avaliadas criticamente e contribuam para um banco de dados sobre ações, para uso por outros. A partir de uma perspectiva do ensino, é importante que cuidados sejam tomados para garantir a adequação de um conjunto de ações para os estudantes envolvidos, em particular, e a viabilidade geral do projeto, em termos de tempo e recursos. Distinções entre a aprendizagem sobre a ação, a aprendizagem através da ação e aprendizagem a partir da ação (MCCLAREN; HAMMOND, 2005) podem ser úteis no planejamento de intervenções. 


\section{Aprendendo sobre, através e a partir da ação}

A aprendizagem sobre a ação se concentra em aprender as habilidades e estratégias de ação sociopolítica através de filmes, biografias e autobiografias, estudos de caso e simulações, role-play e reconstruções dramáticas. Oferecer aos estudantes exemplos de ações bem-sucedidas, de preferência envolvendo outros estudantes, fomenta a crença de que eles podem mudar as coisas também. É aqui que um banco de dados de ações pode ser especialmente útil. Os estudantes podem aprender a partir das experiências dos outros, isto é, ouvindo e/ou lendo as histórias daqueles que têm estado intimamente envolvidos em tais projetos e abordagens detalhadas de ações realizadas por indivíduos, grupos e comunidades. Schusler e colaboradores (2009) fornecem muitos conselhos úteis sobre como os pesquisadores podem proceder à coleta desse tipo de história oral, fazendo perguntas, tais como: o que lhe motivou ou lhe inspirou a se envolver neste tipo de trabalho? Quais foram os seus objetivos, esperanças e expectativas? Como é que este projeto aconteceu? Quem esteve envolvido? Que barreiras e problemas foram encontrados? Como eles foram abordados? Que sucessos ocorreram? Que falhas ocorreram? $\mathrm{O}$ que você aprendeu? O que surpreendeu, encantou ou decepcionou você? O que você faria diferente se estivesse começando de novo? Você faria isso de novo?

Aprender através da ação compreende o envolvimento direto em projetos orientados para a ação fora da sala de aula que são susceptíveis de ter desfechos e consequências palpáveis. Enquanto alguns projetos podem ser escolhidos e organizados pelo professor, especialmente nos primeiros anos, é importante que os estudantes estejam eles mesmos envolvidos, tão logo seja possível, na seleção e no planejamento das ações a serem tomadas. É importante envolver os estudantes em atividades de pesquisa orientadas por QSC e apoiá-los na participação em organizações de base comunitária que concentram os cidadãos para lidar com questões locais graves, em particular aquelas questões muitas vezes esquecidas pelas agências ou instituições governamentais. Ao enfrentar as questões locais reais diretamente, os estudantes ganham valiosa experiência em primeira mão das maneiras em que interesses sociais, políticos e econômicos concorrentes impactam na tomada de decisões. Através da participação em atividades baseadas na comunidade, eles ganham acesso às ideias, às experiências, às pessoas, às instituições e às estruturas sociopolíticas que constroem tanto a capacidade individual quanto a coletiva para abordar QSC e as questões ambientais de forma responsável, profunda, crítica e politicamente efetiva e construir o compromisso de se engajar na luta por maiores liberdade, igualdade e justiça social.

Ao se envolverem nos assuntos públicos a nível local, os estudantes veem os processos democráticos em ação; trabalhando ao lado de outros, eles aprendem sobre as demandas e dificuldades de agir e aprender a desenvolver estratégias eficazes de enfrentamento. Uma pesquisa sugere que a participação nesses tipos de atividades na infância e na adolescência está associada a níveis de participação cívica, serviços à comunidade e ativismo político na idade adulta até quatro vezes maior do que a norma. (CHAWLA; 
FLANDERS CUSHING, 2007) Através do envolvimento em audiências públicas e em reuniões da câmara municipal, conferências de consenso, círculos de estudo, grupos focais, painéis/júris de cidadãos, fóruns para elaboração de regras negociáveis e comitês de aconselhamento público, os estudantes ganham autonomia, um senso de valor e competência, uma sensação de identidade pessoal e cívica, o respeito pelos outros pontos de vista das pessoas, habilidades de negociação e assim por diante. Ao trabalhar em uma subtarefa, dentro de um esforço de grupo, os indivíduos adquirem um nível de conhecimento que não seria alcançado sozinho, pelo menos não tão rapidamente e de forma indolor. Eles também entram em contato com perspectivas sobre questões e problemas que diferem das suas. Compartilhar experiências, estratégias de ação e histórias de sucesso, bem como construir amizades, pode ser inspirador e altamente motivador e pode levar ao ativismo sociopolítico ao longo da vida.

A aprendizagem a partir da ação ocorre quando os estudantes avaliam os planos, estratégias, processos e resultados dos seus próprios projetos de ação e aqueles dos outros. A análise leva à compilação de um registro do que aconteceu ou do que os estudantes percebem como tendo acontecido, das tentativas para identificar o porquê sim ou o porquê não de uma ação ter sido bem-sucedida, e a uma reflexão por todas as partes envolvidas sobre a importância da ação para si e para a comunidade. O processo é facilitado pela manutenção de registros cuidadosos e também de jornais sobre o assunto, consulta com outros, compartilhamento de experiências e sentimentos e comunicação com todos aqueles envolvidos. É importante que uma determinada ação não seja vista como um fim em si. Os estudantes precisam de oportunidades para avaliar as ações realizadas, para refletir sobre sua natureza e impacto e, possivelmente, reformular a ação. A questão, de modo simples, é que uma orientação positiva para a ação sociopolítica seja estabelecida ao longo do tempo e esteja enraizada na prática reflexiva.

Os estudantes podem ganhar experiência de ação e, assim, aprender através da ação e também a partir da ação, por meio da abordagem já conhecida de aprendizagem em três fases, compreendendo modelagem, prática guiada e aplicação, como discutido acima. Ao se envolver em intervenções e projetos orientados para a ação, em paralelo com uma crítica qualificada e confiável, os estudantes aumentam tanto a sua compreensão do que constitui a ação sociopolítica, quanto sua capacidade de praticá-la com sucesso. Em outras palavras, o ativismo social é uma atividade reflexiva: conhecimento e perícia informam e determinam a condução da atividade e, simultaneamente, o envolvimento em ações (e reflexão crítica sobre elas) refina o conhecimento e aguça a perícia. Ao longo de todas estas atividades, o papel do professor é crucial: um ativista modelo, um orientador, um recurso de aprendizagem, um facilitador, um consultor, um suporte emocional e também um crítico. Também, porque os alunos têm a oportunidade de experimentar o fracasso, bem como o sucesso, é imperativo que a atmosfera das aulas seja tanto tolerante quanto solidária e que exista um diálogo permanente sobre a forma como a atividade está progredindo, incluindo uma discussão franca dos problemas encontrados, 
rotas de investigação que se mostram estéreis e barreiras ao progresso que se mostram intransponíveis. Crucial também, se o objetivo é que os estudantes ganhem uma compreensão da autêntica ação sociopolítica, seria uma comparação constante entre o que os estudantes estão fazendo em seu projeto e o que os outros fizeram. Da mesma forma que é importante ensinar aos estudantes a necessidade de serem resilientes e determinados para tentar novamente, experiências de fracasso também podem lhes mostrar a necessidade de mobilizar os outros e de se envolver em uma ação coletiva. Ações coletivas são quase sempre mais efetivas que ações individuais e, em algumas circunstâncias, podem ser o único meio de conduzir à mudança.

\section{Considerações finais}

Se estamos a preparar os estudantes para lidar com questões controversas de forma racional, diligente, tolerante e moral, é preciso garantir que eles tenham os conhecimentos, habilidades, atitudes e confiança para investigar diversos pontos de vista, analisá-los e avaliá-los, reconhecer inconsistências, contradições e insuficiências, chegar a suas próprias conclusões, argumentar de forma coerente e persuasiva sobre os seus pontos de vista, usá-los nas tomadas de decisões sobre o que é certo, bom e justo num contexto ou situação particular e formular cursos adequados e eficazes de ação. Este capítulo centra-se sobre o tipo de educação científica necessária como preparação para a realização de ações adequadas, responsáveis e eficazes em questões de interesse social, econômico, ambiental e ético-moral. O principal objetivo é permitir que os cidadãos jovens observem criticamente a sociedade que temos, os valores que a sustentam, e que perguntem o que pode e o que deve ser alterado, a fim de alcançar uma democracia socialmente mais justa e resultar em estilos de vida ambientalmente mais sustentáveis.

$\mathrm{Na}$ defesa de um modelo de currículo em quatro estágios, a minha intenção não é sugerir que toda a ação seja atrasada até os anos finais da escolaridade. Ao invés disso, os estudantes devem seguir, a qualquer que seja o estágio apropriado para a QSC específica sob consideração, as oportunidades de aprendizagem que ela apresenta e o nível de desenvolvimento intelectual e emocional dos estudantes, tendo em conta o princípio de gerenciamento de aulas que consiste em, para cada tópico, investir em uma variedade de abordagens. Em algumas áreas de atuação, é relativamente fácil que os estudantes se organizem para a ação; em outras áreas, é mais difícil. Para algumas QSC, o estágio 3 é mais trabalhoso do que o estágio 4. Por exemplo, é mais fácil realizar uma ação sobre a reciclagem do que alcançar um juízo crítico e de alta reputação acerca da reciclagem versus o consumo reduzido versus o uso de materiais alternativos. Além disso, é improvável que todos os estudantes sejam motivados pelas mesmas questões, problemas ou situações, e é provável que os indivíduos variem substancialmente em suas disposições para agir. Claramente, essas diferenças tornam difícil planejar um currículo orientado para a ação, para todos. Mas não há nenhuma razão pela qual devemos esperar que diferentes 
estudantes e grupos de estudantes participem do mesmo projeto. Diferentes pontos de vista e diferentes prioridades poderiam, e possivelmente devem, levar à participação em diferentes projetos.

Os estudantes que estão acostumados com um currículo de ciências tradicional estarão familiarizados com a ciência sendo apresentada como inteiramente racional, sistemática, analítica, despersonalizada e sem emoção, com poucas oportunidades para explorar sentimentos, sensibilidades e emoções. Quando confrontados com uma abordagem orientada a QSC, tais estudantes poderão ser surpreendidos por suas respostas emocionais para QSC e questões ambientais controversas pelo debate vívido e excitante em sala de aula. Se os aprendizes não têm capacidade para lidar com seus distúrbios emocionais ou para lidar com seus impulsos, torna-se difícil para eles se envolverem em atividades de aprendizagem, avaliar diferentes opções, aplicar julgamentos maduros e fundamentados e assumir a responsabilidade para sintetizarem seus pontos de vista. O contexto social em que o estudante está, localizado fora da escola, pode ser um importante fator de impacto sobre a aprendizagem. Rejeitar conhecimentos e crenças que são fortemente sustentados dentro de grupos sociais aos quais o estudante pertence, ou pretende ser incluído, pode ser tão emocionalmente estressante que se torna praticamente impossível. Da mesma forma, aceitar pontos de vista que estão em oposição às visões dominantes dentro desses grupos pode ser uma tarefa descomunal. $O$ senso de identidade de um estudante, incluindo etnia, gênero, classe social, relações familiares e comunitárias, estatuto econômico e experiências pessoais se estendendo ao longo de muitos anos vai necessariamente ter impacto sobre seus valores, prioridades e preferências. É aqui que as noções de inteligência emocional, de letramento emocional e de competência emocional, e as estratégias de ensino para promovê-las, podem ser úteis - temas bem fora do foco deste capítulo, ainda que possamos notar que o envolvimento emocional pode ser promovido através de estudos de caso, teatro, encenações, literatura, arte, fotografias, filmes e música, visitas a lugares específicos, entrevistas com aqueles diretamente afetados e assim por diante. Atividades de escrita podem também desempenhar um papel importante no desenvolvimento do investimento pessoal em uma questão e na sensibilização crescente dos estudantes para a necessidade de ação sociopolítica, especialmente quando os estudantes assumem o papel de um jornalista investigativo. Visitas a locais específicos (hospitais, fazendas industriais, laboratórios etc.) e experiências guiadas em áreas de importância ecológica podem desempenhar um papel profundo na sensibilização e no engajamento emocional dos estudantes.

Um papel central pode ser desempenhado pela familiaridade dos estudantes com mídias sociais, como o Facebook e o Twitter, para estabelecer redes, expressar preocupações, partilhar pensamentos e espalhar mensagens sobre a necessidade de ações. As mídias sociais permitem formas de participação que não eram possíveis anteriormente e podem engajar números significativos de pessoas que de outra forma não seriam envolvidas. Elas têm o potencial de facilitar a construção de uma sociedade mais inclusiva, 
participativa, socialmente justa e politicamente engajada. Remtulla (2008) identifica três categorias de atividade política online:

- o uso consciente e comprometido da internet e de outras formas de TIC como um meio de acessar fontes independentes e alternativas de informação que podem ser ignoradas ou suprimidas pela mídia hegemônica - por exemplo, o Centro de Mídia Independente, ${ }^{10}$ Wikinotícias $^{11}$ e DemocracyNow; ${ }^{12}$

- sites orientados para a comunidade que buscam difundir conscientização, compartilhar experiências e ideias e construir redes dentro das comunidades; e

- grupos de ação aumentam o apoio público para as ações relacionadas com questões específicas (locais, regionais, nacionais e internacionais).

Nós precisamos estar cientes, no entanto, de que as desigualdades sociais e o acesso diferenciado aos recursos tecnológicos podem restringir as oportunidades para aqueles que já são marginalizados, não ouvidos ou desconsiderados. Eles podem ser ainda mais desfavorecidos, silenciados ou mesmo excluídos da participação na abordagem dos problemas que mais os afetam. Serão necessários esforços massivos para assegurar que os espaços online e as comunidades que os utilizam sejam abertos a todos.

Os estudantes devem ser encorajados e habilitados a utilizar os aspectos da cultura da juventude para espalhar uma mensagem orientada para os jovens, sobre a responsabilidade cívica e ambiental. A música pode ser importante na construção e na consolidação da identidade, ajudando os estudantes a obter uma melhor compreensão das suas próprias experiências e das experiências dos outros, melhorando a conscientização política e construindo a solidariedade e o senso de comunidade/pertencimento que pode levar ao ativismo. Para muitos jovens urbanos nos Estados Unidos, a música rap da cultura hip-hop pode ser um veículo particularmente poderoso, permitindo-lhes colocar seus sentimentos, emoções, necessidades, aspirações, esperanças, alegrias, medos, desilusões e raiva em uma forma que respeita as suas experiências culturais imediatas e será facilmente entendida por seus pares. ${ }^{13}$ Por exemplo, Ginwright e Cammarota (2007) descrevem como jovens em Oakland (Califórnia, Estados Unidos) organizaram o que eles chamam de "hip-hop de guerrilha urbana" - concertos móveis improvisados com música, rap, distribuição de folhetos e outras formas de educação política em parques locais, centros comerciais, esquinas e outros lugares para onde os jovens costumam sair.

10 Ver em: <www.indymedia.org>; <http://www.midiaindependente.org/>.

11 Ver em: <en.wikinews.org>; <https://pt.wikipedia.org/wiki/Wikinot\%C3\%ADcias>.

12 Para fontes de informação brasileiras, sugerimos consultar notas 3 e 4, dos organizadores, acima. Ver em: <www.democracynow.org $\rangle$. (N. do O.).

13 Assim como também ocorre em muitas grandes cidades latino-americanas. (N. do O.). 
É claro que nem todas as atividades orientadas por QSC, baseadas na comunidade, serão bem-sucedidas na promoção, no desenvolvimento e na manutenção de uma postura ativista. Existe o perigo de que as ações reflitam a agenda do professor e não os interesses e as preocupações dos estudantes, que simplesmente seguiriam o movimento, indo com a maioria, sem engajamento na ação, sem qualquer compromisso real ou sentimento de poder, simplesmente para satisfazer os requisitos do curso ou atender às expectativas do professor. No caso extremo, os professores podem ser levados a compilar uma lista de ações aprovadas, roteirizadas e politicamente seguras nas quais envolveriam grupos sucessivos de estudantes sem sequer envolvê-los no debate crítico que deve preceder e determinar a ação. Os estudantes podem ser dirigidos para questões incontroversas, guiados para longe do conflito, dissuadidos do debate político e censurados quando suas propostas parecem propensas a desafiar práticas escolares, políticas governamentais locais ou os interesses de empresas locais. Estas situações devem ser evitadas. Simovska (2008) distingue entre a participação simbólica e a participação genuína em termos de "foco" (conteúdo especificados versus a construção do conhecimento através de crítica e reflexão), "resultados" (aceitação de um determinado conjunto de crenças, valores e comportamentos versus a autonomia e a consciência crítica do estudante, assim como sua capacidade de lidar com questões novas e complexas) e "objetivos de mudanças" (indivíduos e seus respectivos estilos de vida versus indivíduos em contexto, tendo em conta as relações interpessoais, os fatores socioculturais, as dimensões ético-morais e as estruturas organizacionais existentes). As mesmas preocupações estão presentes na insistência de Roth (2009) de que os professores não subordinem a experiência de ativismo aos objetivos mais gerais de escolaridade e também tenham em conta - através da observação de Sammel e Zandvliet (2003) - de que a maioria das abordagens de QSC nas escolas são realizadas dentro da percepção dos limites do politicamente aceitável para os professores. É imperativo que os professores encontrem a coragem, recrutem o apoio de outras pessoas e mobilizem os recursos para serem muito mais desafiadores, críticos e politizados em suas abordagens. Muitos professores consideram que evitar questões controversas, especialmente aquelas com dimensões políticas muito significativas, é assumir uma posição neutra. Na realidade, não é neutra. Porque ela falha ou deixa de enfrentar e desafiar as causas sociopolíticas subjacentes dos problemas ambientais, por exemplo, ela suporta implicitamente práticas sociais vigentes, as instituições e os valores atuais. Não existe tal coisa como não envolvimento político. Não envolvimento é, em si, uma forma de envolvimento pelo que é padrão, pelo que é norma e constitui, assim, um apoio implícito à ideologia dominante. Evitar questões políticas é, com efeito, deixar tais questões para que outros decidam.

Claro, há professores que vão argumentar que a politização não é uma meta legítima da educação em ciência e tecnologia (ou de qualquer educação baseada na escola, na medida em que possa ser considerada) e que a ação sociopolítica não tem qualquer lugar na escola. Abordar QSC controversas em sala de aula pode provocar a oposição 
de outros professores, administradores escolares, pais e membros da comunidade local. Engajar os estudantes em ações sociopolíticas pode provocar ainda mais oposição. Apesar de que a reciclagem, a limpeza de praia, a construção de caixas-ninho ou o trabalho no banco local (local foodbank) ou em um abrigo para pessoas sem-teto podem ser ações consideradas seguras, benignas e não controversas, desafiar autoridades locais, organizar manifestações, realizar vigílias e organizar boicotes pode elevar os níveis de ansiedade dos pais, ofender a comunidade local e levar a uma oposição continuada. Os professores precisam estar preparados para a repercussão, e eles precisam de coragem para ir claramente contra esta oposição. Muitos vão perceber a capacidade para efetuar uma mudança social localizada em um corpo de estudantes que são cientificamente letrados, ambientalmente conscientes, socialmente críticos e politicamente letrados como uma ameaça ao invés de um benefício, como uma ameaça à ordem estabelecida de poder e controle. De fato, o próprio sucesso da educação advogada neste livro é o que é susceptível de atrair a maior parte da oposição, de modo que o envolvimento dos estudantes em ações políticas potencialmente bem-sucedidas poderá ser vigorosamente resistido. Como observado em Hodson (2014), aqueles professores que promovem o envolvimento e desenvolvem capacidades para a ação estão montando um tigre, mas é um tigre que pode muito bem ter de ser montado, se realmente queremos dizer o que nós dizemos sobre a educação para a participação cívica. Eu não procuro minimizar as dificuldades que os professores enfrentam para implementar um currículo orientado para a ação ou a coragem que eles precisarão para se colocar de forma contrária a esta resistência potencialmente muito forte. No entanto, faço um clamor aos professores e aos estudantes para que tenham a coragem e a força de vontade para fazer o que eles acreditam que é correto, bom e justo. Nas palavras de Alberto Rodriguez (2001, p. 290), nós precisamos de coragem para "expandir o nosso olhar [...] e enfrentar o desafio de nos tornarmos guerreiros culturais para a mudança social”.

\section{Referências}

AGYEMAN, J.; CARMIN, J. Introduction: Environmental injustice beyond borders. In: CARMIN, J.; AGYEMAN, J. (Ed.). Environmental inequalities beyond borders: local perspectives on global injustices. Cambridge, MA: MIT Press, 2011. p. 1-15.

ALLCHIN, D. Teaching the nature of science: perspectives and resources. Saint Paul, MN: SHiPS Education Press, 2013.

ANGELL, M. The truth about the drug companies: how they deceive us and what to do about it. New York: Random House, 2004.

BISSCHOP, L. How e-waste challenges environmental governance. International Journal for Crime, Justice and social Democracy, Brisbane, v. 3, n. 2, p. 81-95, 2014.

BONJOUR, L.; BAKER, A. (Ed.). Philosophical problems: an annotated anthology. New York: Pearson Longman, 2007. (Specifically, chapter 5: Morality and moral problems). 
BROOKE, J. Waste dumpers turn to West Africa. The New York Times, New York, Jul. 1988.

BULLARD, R. D.; JOHNSON, G. S. Environmental justice: grassroots activism and its impact on public policy decision making. Journal of Social Issues, Malden, v. 56, n. 3, p. $555-578,2000$.

BURBULES, N. C.; CALLISTER, T. A. Watch it: the risks and promises of information technologies for education. Boulder, CO: Westview Press, 2000.

CHAWLA, L.; FLANDERS CUSHING, D. Education for strategic environmental behavior. Environmental Education Research, Abingdon, v. 13, n. 4, p. 437-452, 2007.

CHOPRA, S. Globalisation, food security, public health \& prosperity focus on India. Journal of Activist Science \&Technology Education, [S.1.], v. 1, n. 1, p. 61-64, 2009.

ELAM, M.; BERTILSSON, M. Consuming, engaging and confronting science: The emerging dimensions of scientific citizenship. European Journal of Social Theory, London, v. 6, n. 2, p. 233-251, 2003.

ERDURAN, S.; DAGHER, Z. R. Reconceptualizing the nature of science for science education. Dordrecht: Springer, 2014.

FRANCE, B.; MORA, H. A.; BAY, J. B. Changing perspectives: Exploring a pedagogy to examine other perspectives about stem cell research. International Journal of Science Education, London, v. 34, n. 5, p. 803-824, 2012.

FULLICK, P.; RATCLIFFE, M. (Ed.). Teaching ethical aspects of science. Totton: Bassett Press, 1996.

GINWRIGHT, S.; CAMMAROTA, J. Youth activism in the urban community: Learning critical civic praxis within community organizations. International Journal of Qualitative Studies in Education, Basingstoke, v. 20, n. 6, p. 693-710, 2007.

GREENPEACE. Poisoning the poor: electronic waste in Ghana. Amsterdam, 2008.

HALVERSON, K. L.; SIEGEL, M. A.; FREYERMUTH, S. K. Lenses for framing decisions: undergraduates' decision making about stem cell research. International Journal of Science Education, London, v. 31, n. 9, p. 1249-1268, 2009.

HODSON, D. Becoming part of the solution: learning about activism, learning through activism, learning from activism. In: BENCZE, L.; ALSOP, S. (Ed.). Activist science and technology education. Dordrecht: Springer, 2014. p. 67-98.

HODSON, D. Don't be nervous, don't be flustered, don't be scared: be prepared. Canadian Journal of Science, Mathematics and Technology Education, Toronto, v. 13, n. 4, p. 313-331, 2013.

HODSON, D. Looking to the future: building a curriculum for social activism. Rotterdam: Sense Publishers, 2011.

HODSON, D. Teaching and learning about science: language, theories, methods, history, traditions and values. Rotterdam: Sense, 2009. 
HURSTHOUSE, R. On virtue ethics. Oxford: Oxford University Press, 1999.

IBITAYO, W. C. G. Transboundary dumping of hazardous waste. In: THE ENCYCLOPAEDIA of earth. Washington: Environmental Information Coalition, National Council for Science and the Environment, 2008.

KELLY, T. Discussing controversial issues: four perspectives on the teacher's role. Theory and Research in Social Education, New York, n. 14, p. 113-138, 1986.

KNIGHT, A. J. Perceptions, knowledge and ethical concerns with GM foods and the GM process. Public Understanding of Science, Bristol, n. 18, p. 177-188, 2009.

KOLSTØ, S. D. Scientific literacy for citizenship: tools for dealing with the science dimension of controversial socioscientific issues. Science Education, New York, v. 85, n. 3, p. 291-310, 2001.

KYLE JR., W. C. Editorial: the importance of investing in human resources. Journal of Research in Science Teaching, New York, n. 33, n. 1, p. 1-4, 1996.

MARTINEZ-ALIER, J. The environmentalism of the poor: a study of ecological conflicts and valuation. Northhampton, MA: Edward Elgar Publishing, 2003.

MCCLAREN, M.; HAMMOND, B. Integrating education and action in environmental education. In: JOHNSON, E. A.; MAPPIN, M. J. (Ed.). Environmental education and advocacy: changing perspectives of ecology and education. Cambridge: Cambridge University Press, 2005. p. 267-291.

PEDRETTI, E. Septic tank crisis: a case study of science, technology and society education in an elementary school. International Journal of Science Education, London, v. 19, n. 10, p. 1211-1230, 1997.

QUALIFICATIONS AND CURRICULUM AUTHORITY-QCA. Education for citizenship and the teaching of democracy in schools. London, 1998.

RAI, T.; NORTON, T. Discourses of sustainability in today's public sphere. In: MAY, S. K.; CHENEY, G.; ROPER, J. The Debate over Corporate Social Responsibility. Oxford: Oxford University Press, 2007, p. 351-364.

REMTULLA, K. A. Democracy or digital divide? the pedagogical paradoxes of online activism. In: LIND, D. E.; CARR, P. R. (Ed.). Doing democracy: striving for political literacy and social justice. New York: Peter Lang, 2008. p. 267-280.

RODRIGUEZ, A. J. Courage and the researcher's gaze: (re)defining our roles as cultural warriors for social change. Journal of Science Teacher Education, New York, v. 12, n. 3, p. 277-294, 2001.

ROTH, W-M. On activism and teaching. Journal of Activist Science and Technology Education, [S.1.], v. 1, n. 2, p. 33-47, 2009.

SAMMEL, A.; ZANDVLIET, D. Science reform or science conform: problematic epistemological assumptions with/in Canadian science reform efforts. Canadian Journal of Science, Mathematics and Technology Education, Toronto, v. 3, n. 4, p. 513-520, 2003. 
SCHUSLER, T. M. et al. Developing citizens and communities through youth environmental action. Environmental Education Research, Abingdon, v. 15, n. 1, p. 111-127, 2009.

SHEN, B. S. P. Scientific literacy and the public understanding of science. In: DAY, S. B. (Ed.). The communication of scientific information. Basel: Karger, 1975. p. 44-52.

SIMOVSKA, V. Learning in and as participation: a case study from health-promoting schools. In: REID, A. et al. (Ed.). Participation and Learning: perspectives on education and the environment, health and sustainability. New York: Springer, 2008. p. 61-80.

SINGER, P. (Ed.). Companion to ethics. Oxford: Basil Blackwell, 1991.

STELFOX, H. T. et al. Conflict of interest in the debate over calcium channel antagonists. New England Journal of Medicine, Boston, v. 338, n. 1, p. 101-106, 1998.

YOUNG, R. M. Racist society, racist science. In: GILL, D.; LEVIDOW; L. (Ed.). Antiracist science teaching. London: Free Association Books, 1987. p. 16-42. 